\title{
Investigating Learners' Perception of Uncertainty Level and satisfaction in learning experience in an Authentic Problem-based Learning Classroom
}

\section{Dr. Loh Kah Heng}

Taylor's University, Malaysia.

Correspondence Author: Dr. Loh Kah Heng, Taylor's University, Malaysia.

E-mail: loh.kahheng@taylors.edu.my, 0356295404

Received date: 12 January 2018, Accepted date: 10 March 2018, Online date: 2 April 2018

Copyright: @ 2018 Dr. Loh Kah Heng. This is an open-access article distributed under the terms of the Creative Commons Attribution License, which permits unrestricted use, distribution, and reproduction in any medium, provided the original author and source are credited.

\begin{abstract}
Learners of Problem-based learning (PBL) are expected to gain learning experience from "real world" problems through uncertainty resolution alongside with the problem solving process. The uncertainty incorporated in the authentic PBL problem acts as a source of intrinsic motivation and a stimulus to learning which appears as the natural provocations for real learning experience. PBL learners must seek information to resolve uncertainty in various stages of the problem solving process. This paper aims to investigate the perception of PBL learners with regards to their uncertainty level and satisfaction in learning experience while following an authentic PBL approach in learning physics. 78 students (FALL 2016 Semester) from American Degree Transfer Program at Taylor's University in Malaysia participated in this study. These PBL learners were randomly assigned into two equal groups. The independent variables were groups of students with and without pretesting while dependent variables were PBL learners' perception of uncertainty level and satisfaction in learning experience. Uncertainty construct was developed and designed to measure an individual's real or anticipated uncertainty level with regards to the cognitive, affective and physical dimension in a 30-item selfreporting, numerically measurable questionnaire. Satisfaction in learning experience will measure learners' satisfaction in learning experience with regards to the benefits through construction and made sense of the information gathered and knowledge acquisition, and application of the acquired knowledge to perform the learning task in a 10-item self-reporting, numerically measurable questionnaire. The pre-test and post-test questionnaires consist of 40 items with high reliability, that is Cronbach's Alpha of 0.852 (pre-test instrument) and 0.882 (posttest instrument) for the survey questionnaire. Results from the analysis of repeated T-tests and independent sample T-Tests showed that PBL learners' uncertainty level was reduced while satisfaction in learning experience was increased after attending the authentic PBL activities. Besides, the Pearson's correlation coefficient between the decrease in uncertainty level and increase in rating of satisfaction in learning experience were statistically correlated.
\end{abstract}

Key words: Authentic Problem-Based Learning, Uncertainty, Learning Experience, Outcome-Based Education

\section{INTRODUCTION}

In the traditional approach which practices rote learning, teaching and learning through repeatedly memorizing is considered as a way of uncertainty reduction. This scenario has perfectly reflected in our primary and secondary education system in Malaysia schools. According to Blumenfeld [1] this approach is suitable for young students, but not for university students who need to learn how to learn and empowered in their own learning. This scenario is clearly specified through the following statement given by World Health Organization [2]:

'The explosion of scientific information makes traditional curricula increasingly irrelevant, because they are based on what is known today, to exclusion of how to learn what will be known tomorrow'.

Shift of paradigm from traditional teaching system to student-centered learning has been observed and debated in the past decades with regards to the effect of learning experience of the students. Many universities and academics have realized the importance of outcome-based education as oppose to the rigidity of curricular-based education. Most universities nowadays recognize that learning paradigm is more beneficial to both teachers and students in that it engages and empowers the student in the content and opens a broad variety of techniques beyond the standard lecture to encourage faculty to stay fresh and current in their field, and get involve in their students' progress [3]. They have recognized the philosophy of John Dewey that "true learning is based on discovery guided by mentoring rather than the transmission of knowledge". Burch [3] reported that recent research has shown that PBL is the most effective technique for students to learn, apply, integrate and retain information. In order to promote this learning paradigm, the students must possess certain characteristics such as high level of communication skills, ability to identify and define problems, seeking and evaluating information from the suitable information sources and use it to reduce uncertainty about the problems and enhance their learning experience. Students must be able to work and share with others to use all of the characteristics to address problems in a complex real-world setting. In the learning paradigm, the teachers are changing their role to become facilitators of learning to help students, and students will be changing their role from passive knowledge receivers to active information seekers and self-directed learners by selecting appropriate information sources and seeking new information to reduce uncertainty as well as construct new knowledge rather than just regurgitating old information [4]. The repeated opportunities for seeking, evaluating, managing, and applying information gathered from multiple sources using discipline specific research methods enables students to develop a meta-cognitive approach to learning, making them conscious of the explicit actions required. Many countries in the world are shifting their focus to gradually adopt this approach to produce educated graduates and future knowledge workers in line with the comments from the Boyer Commission Report [5] on undergraduate education at research universities: 
"The research university must facilitate inquiry in such contexts as the library, the laboratory, the computer, and the studio, with the expectation that senior learners, that is, professors, will be students' companions and guides. The research university's ability to create such an integrated education will produce a particular kind of individual, one equipped with a spirit of inquiry and a zest for problem solving; one possessed of the skill in communication that is the hallmark of clear thinking as well as mastery of language; one informed by a rich and diverse experience. It is that kind of individual that will provide the scientific, technological, academic, political, and creative leadership for the next century."

In the context of Malaysia Higher education, students will experience abrupt change in the learning environment which shifts from instructional approach to constructivist approach such as PBL. This is due to the fact that our students who have completed secondary education are highly dependent on teachers who spoon fed them with knowledge to reduce uncertainty in learning. It is known that one of the unique features of PBL is to present the ill-structured real-world problems to students before they are taught with the topic or knowledge [6], and these problems incorporate uncertainty naturally as a source of intrinsic motivation and stimulus to their learning [7]. According to Keller, PBL approach which is associated with challenge, incongruity, anomaly, and discrepant event in the problem cause the university students to experience cognitive dissonance. They will struggle with uncertainty and ambiguity as they proceed to craft their own problem statements [8]. They have to seek much more new information and explore for new knowledge to reduce their uncertainty level. Much of the reported dissatisfaction [9] with the course conducted in PBL approach can probably be attributed to the fact that students are anxious about the incompleteness and uncertainty arises in their own independent learning. As the higher education in Malaysia is currently emphasizing on outcome-based education (OBE) where PBL is considered as one of the learning approach under the framework, reducing level of uncertainty has emerged as an important construct in measuring their learning experience. An authentic PBL approach is important to empower PBL learners to gain desired knowledge independently with authentic tasks/ problems so as to effectively reduce their uncertainty level and increasing their rating in satisfaction in learning experience.

This study will investigate the PBL learners' perception of uncertainty level, rating in satisfaction in learning experience, as well as the correlation between the decrease in uncertainty level and increase in rating in satisfaction of learning experience after attending an authentic PBL approach.

\section{Problem Statement:}

Many academics in universities believe that the shift to the outcome-based education will enable students to consciously and constructively design their learning paths throughout their higher education experience. This will make them more marketable and increase their employability once they have completed their study in the university. Being a popular learning approach in outcome-based education, Problem-based learning (PBL) is one of the student-centered learning approach (SCL) which empowered individual student to have 100 percent responsible for his own behavior, participation and learning [10]. For university students, PBL approach offers a flexible and responsive method of learning whilst simultaneously meeting national quality guidelines [11]. In the authentic PBL classroom, ill-structured "real world" problems which incorporate uncertainty provokes real learning. The existence of uncertainty causes students to become active information seekers to reduce uncertainty. It is more relevance for educators to focus on the knowledge that students actually need to solve the problem.

However, for students who have been following Malaysia education system which over-emphasizing on examination-oriented culture, they will experience high level of anxiety and uncertainty in learning experience due to the sudden change in the education approach in university. The examination-oriented education system treats teachers as the sages of the stage who have full control over the content of the knowledge to be delivered to students. Meanwhile, students will just receive and memorize all the content knowledge within the syllabus to reduce uncertainty and obtain a good grade in examination. Students are spoon fed with the "prepackaged knowledge" with examination results serve as an indicator of uncertainty reduction and achievement in learning experience. Their uncertainty level will be effectively reduced by absorbing the information bombarded to them by the teachers and text books as well as completing assignments and practiced on the past years series of exam papers. Some disgruntled students will not appreciate at the beginning and they will begin to complaint to the management about their frustration [12]. This situation can be resolved by adopting an authentic PBL approach to soften the uncertainty reduction process in their process of filling up the gap of knowledge during knowledge acquisition in the various stages of problem solving process, which acts as uncertainty resolution process in the authentic PBL approach.

\section{The Authentic PBL Approach:}

For adult learners such as university or college students, PBL is viewed as an appropriate approach to create learning. PBL is purported to empower learners by encouraging them to take a deep approach to their own learning and to become more confident and self-directed in their learning. It incorporates uncertainty which provokes real learning. Students are actively engaging in information seeking to reduce uncertainty during their learning process. Students develop knowledge, skills and attitude in various stages of problem solving process in an authentic PBL approach. Woods [13] summarizes the characteristics of PBL approach which includes:

- Just in time learning: students learn information, skills and attitudes to solve problem.

- $\quad$ Problem posed first prior to student learned anything.

- $\quad$ Students empowered with selecting learning goals, resources, and assessments.

- Work cooperatively in small groups.

- Lecturers become the guide on the side to monitor the process and no longer the sage on the stage.

- $\quad$ Students actively engaged in the learning process.

These characteristics seem so appealing in the new education environment, particularly in this information era where information is generated exponentially, and students must have the skills to add on the relevant information to their existing knowledge base.

The Authentic PBL approach in this study is adapted and combined from APBL model [8] and the RP's "one-day, One-Problem" approach to PBL [14] which is built around Wilson Problem-solving model [15]. This authentic PBL approach is conducted on Saturday from 8 am to 5 pm to avoid causing disruption to students' time-table.

In this authentic PBL model, students undertaking Physics course will be given a "real world" problem which land them to the following "TIPS" [8] stages

- Trigger their learning, students will encounter high uncertainty level and curiosity when they receive a problem which is beyond their existing knowledge to tackle it.

- Inquire and information seeking to clarify and identify the problem for uncertainty resolution by stating the problem statement (During Meeting 1 for uncertainty resolution)

- Propose ideas to manage the problem after seeking more information to fill the knowledge gap for uncertainty resolution (during Meeting 2 for further uncertainty resolution)

- Seek and acquire new knowledge alongside with solving the problem (During meeting 3 to compile the acquired knowledge for further uncertainty resolution).

These stages will be taking place in at least 3 meetings, where each meeting will serve for uncertainty resolution, as shown in figure 1: The Wilson's Problem solving model. 


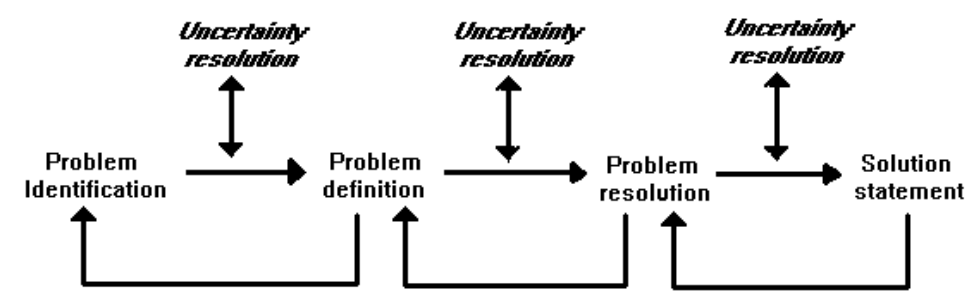

Fig. 1: Wilson's Problem Solving model

Meeting 1 will allow the students to form groups and to be presented with ill-structured problem to trigger learning and curiosity, and stating problem statement and identify existing knowledge and knowledge gap to solve the problem. Individual member will be assigned with specific task and proceed to information seeking process. Meeting 2 will gather information and newly acquired knowledge from all members in the group to make sense of the problem, narrow the knowledge gap and propose further ideas to manage the problem. Individual member will continue to seek information to continue solving the problem. In meeting 3, the knowledge gap will be closed by compiling all the information acquired and present the final solution. The report will be submitted at the end of the day, any time before mid-night (24:00) of the day.

The Purpose of The Study:

The purpose of this study is to provide findings on PBL learners' perception of uncertainty level, satisfaction in learning experience, and the relationship between decrease in uncertainty level and increase in rating of satisfaction in learning experience with the authentic PBL model for the physics course in American Degree Program at Taylor's University, Malaysia.

A set of null hypotheses and its subsidiary null hypotheses of this study were formulated to guide this research.

$\mathrm{H}_{\mathrm{ol}}$ : There is no statistically significant difference in uncertainty level between PBL learners before taking PBL activity and those same PBL learners after following PBL activities.

$\mathrm{H}_{\text {ola: }}$ There is no statistically significant difference in cognitive uncertainty level between PBL learners before taking PBL activity and those same PBL learners after following PBL activities.

$\mathrm{H}_{\text {olb: }}$ There is no statistically significant difference in affective uncertainty level between PBL learners before taking PBL activity and those same PBL learners after following PBL activities.

$\mathrm{H}_{\text {olc: }}$ There is no statistically significant difference in physical uncertainty level between PBL learners before taking PBL activity and those same PBL learners after following PBL activities.

H02: there is no significant different in final uncertainty level between groups of PBL learners with pretest and without pretest

$\mathrm{H}_{03}$ : There is no statistically significant difference in perception of satisfaction in learning experience between PBL learners before taking PBL activity and those same PBL learners after following PBL activities.

$\mathrm{H}_{04}$ : there is no significant difference in perception of satisfaction in learning experience between groups of PBL learners with pretest and without pretest

$\mathrm{H}_{05}$ : there is no statistical correlation between decrease in uncertainty level and increase in rating of satisfaction in learning experience of the PBL learners in the Authentic PBL classroom.

Methodology:

The Sample:

A total of 78 undergraduate students who have registered the Fall-2016 Physics course in American Degree Transfer Program at Taylor's University participated in this study. These participants were randomly assigned to two PBL groups, one group was pre-tested with their perception in uncertainty level and satisfaction in learning experience upon receiving the PBL learning task to identify the problem while the other group without going through the pretesting process. Both groups will be post-tested with the similar variables after completing the PBL task.

Research Design:

Equal number of PBL learners were randomly assigned to group 1 (group with pretest) and group 2 (group without pretest). A carefully crafted ill-structured problem that triggers the learning activity was given to all participants, allocating 20 minutes for them to read through the problem and visualize it. PBL learners from group 1 were given 20 minutes to fill up the pretest questionnaire which measure their initial perception of uncertainty level and satisfaction in learning experience after reading the PBL problem. The pretest instrument was a questionnaire consists of 30 items of uncertainty constructs and 10 items on satisfaction of learning experience in 5 points Likert scale. Group 2 were subdivided into smaller groups of five members and began the normal process of PBL activities and information seeking activity. All participants were post tested on their uncertainty level and satisfaction in learning experience about the learning task at the end of the PBL process after they submitted their report or solution.

\section{Instruments:}

The independent variable of this study was the grouping of the PBL learners. Group 1 consist of PBL learners with pretest and post-test and group 2 consists of PBL learners with post-test only. The dependent variables were student's perception on uncertainty level and satisfaction on learning experience. A carefully crafted "ill-structured" problem that triggered the learning activity was given to all participants, with 20 minutes perusal time. The pretest of uncertainty level and satisfaction of learning experience was administered to PBL learners in Group 1. The pretest instrument is a questionnaire, consists of 30 items of uncertainty construct which record their thinking, feeling and action in terms of cognitive dimension, affective dimension and physical dimension, and 10 items on satisfaction of learning experience in 5 points Likert scale. The PBL learners in group 2 will immediately follow the normal process of PBL and information seeking activity to solve the problem. The dependent variables can be computed using SPSS to determine the score of the uncertainty level in each item attributed to the uncertainty construct and rating in satisfaction in learning experience, which served to reject and fail to reject the null hypotheses.

\section{RESULTS AND DISCUSSION}

The objective of this study was to investigate the PBL learners' perception in uncertainty level, satisfaction in learning experience, and relationship between the degrease in uncertainty level and increase in rating of satisfaction in learning experience after performing an authentic PBL problem in the physics course by computing and studying the learners' uncertainty scores in three dimensions: cognitive, affective and physical. This study will also look into PBL learners' uncertainty resolution and increase in satisfaction in learning experience after completing the authentic PBL task. In order to examine whether these objective were achieved, it was imperative to test all the null hypotheses and the associated subsidiary hypotheses.

Testing of Hypothesis $H_{01}$ and its subsidiary hypotheses:

A paired-samples t-test was conducted to compare uncertainty level of PBL learners before attempting and after completing the learning task with the authentic PBL activities. As indicated in the paired sample t-test statistics shown in table 1, the p-value for each pair is less than 0.05 , thus the Null hypothesis $\mathrm{H}_{01}$ and its associated subsidiary null hypotheses are rejected and in favor of alternative hypotheses. The following results are reported based on the Paired sample ttest statistics 
$\mathrm{H}_{1}$ : There was a significant difference in the total uncertainty level for PBL learners before Authentic PBL $(\mathrm{M}=81.74, \mathrm{SD}=11.86)$ and after Authentic PBL $(\mathrm{M}=70.18, \mathrm{SD}=16.08) ; \mathrm{t}(38)=4.90, \mathrm{p}=0.000$

$\mathrm{H}_{1 \mathrm{a}}$ : There was a significant difference in the cognitive dimension of uncertainty level for PBL learners before Authentic PBL $(\mathrm{M}=22.46, \mathrm{SD}=3.46)$ and after Authentic PBL $(\mathrm{M}=19.21, \mathrm{SD}=4.55) ; \mathrm{t}(38)=5.29, \mathrm{p}=0.000$.

$\mathrm{H}_{16}$ : There was a significant difference in the affective dimension of uncertainty level for PBL learners before Authentic PBL (M=27.00, SD=5.33) and after Authentic PBL $(\mathrm{M}=24.56, \mathrm{SD}=6.25) ; \mathrm{t}(38)=2.05, \mathrm{p}=0.048$.

$\mathrm{H}_{1 \mathrm{c}}$ : There was a significant difference in the physical dimension of uncertainty level for PBL learners before Authentic PBL $(\mathrm{M}=32.28, \mathrm{SD}=5.81)$ and after Authentic PBL (M=26.41, SD=6.60); $\mathrm{t}(38)=5.33, \mathrm{p}=0.000$.

These results suggested that the authentic PBL approach really have impact on uncertainty level. Specifically, our results suggested that when PBL learners underwent the activities specified in the authentic PBL approach, their total uncertainty level and uncertainty level in the cognitive dimension, affective dimen sion and physical dimension will be reduced and resolved. This has indicated that there was learning taking place during problem solving process in the authentic PBL

Table 1: Paired Samples T-test

\begin{tabular}{|c|c|c|c|c|c|}
\hline \multicolumn{6}{|c|}{ Paired Samples Statistics } \\
\hline & & Mean & $N$ & Std. Deviation & $\begin{array}{l}\text { Std. Error } \\
\text { Mean }\end{array}$ \\
\hline \multirow[t]{2}{*}{ Pair 1} & $\begin{array}{l}\text { Total Uncertainty before } \\
\text { PBL }\end{array}$ & 81.7436 & 39 & 11.85819 & 1.89883 \\
\hline & $\begin{array}{l}\text { Total Uncertainty after } \\
\text { PBL }\end{array}$ & 70.1795 & 39 & 16.08018 & 2.57489 \\
\hline \multirow[t]{2}{*}{ Pair 2} & $\begin{array}{l}\text { COGNITIVE dimension of } \\
\text { uncertainty }\end{array}$ & 22.4615 & 39 & 3.45533 & .55329 \\
\hline & $\begin{array}{l}\text { COGNITIVE dimension of } \\
\text { uncertainty }\end{array}$ & 19.2051 & 39 & 4.55481 & .72935 \\
\hline \multirow[t]{2}{*}{ Pair 3} & $\begin{array}{l}\text { AFFECTIVE dimension of } \\
\text { uncertainty }\end{array}$ & 27.0000 & 39 & 5.33114 & .85367 \\
\hline & $\begin{array}{l}\text { AFFECTIVE dimension of } \\
\text { uncertainty }\end{array}$ & 24.5641 & 39 & 6.24835 & 1.00054 \\
\hline \multirow[t]{2}{*}{ Pair 4} & $\begin{array}{l}\text { PHYSICAL dimension of } \\
\text { the uncertainty }\end{array}$ & 32.2821 & 39 & 5.81264 & .93077 \\
\hline & $\begin{array}{l}\text { PHYSICAL dimension of } \\
\text { the uncertainty }\end{array}$ & 26.4103 & 39 & 6.59632 & 1.05626 \\
\hline
\end{tabular}

\begin{tabular}{|c|c|c|c|c|c|c|c|c|c|}
\hline \multicolumn{10}{|c|}{ Paired Samples Test } \\
\hline & & \multicolumn{5}{|c|}{ Paired Differences } & \multirow[b]{3}{*}{$t$} & \multirow[b]{3}{*}{$d f$} & \multirow[b]{3}{*}{ Sig. (2-tailed) } \\
\hline & & \multirow[b]{2}{*}{ Mean } & \multirow[b]{2}{*}{ Std. Deviation } & \multirow{2}{*}{$\begin{array}{l}\text { Std. Error } \\
\text { Mean }\end{array}$} & \multicolumn{2}{|c|}{$\begin{array}{l}\text { 95\% Confidence Interval of the } \\
\text { Difference }\end{array}$} & & & \\
\hline & & & & & Lower & Upper & & & \\
\hline Pair 1 & $\begin{array}{l}\text { Total Uncertainty before } \\
\text { PBL- Total Uncertainty } \\
\text { after PBL }\end{array}$ & 11.56410 & 14.73234 & 2.35906 & 6.78843 & 16.33977 & 4.902 & 38 & .000 \\
\hline Pair 2 & $\begin{array}{l}\text { COGNITIVE dimension of } \\
\text { uncertainty - COGNITIVE } \\
\text { dimension of uncertainty }\end{array}$ & 3.25641 & 3.84378 & .61550 & 2.01040 & 4.50242 & 5.291 & 38 & .000 \\
\hline Pair 3 & $\begin{array}{l}\text { AFFECTIVE dimension of } \\
\text { uncertainty - AFFECTIVE } \\
\text { dimension of uncertainty }\end{array}$ & 2.43590 & 7.42965 & 1.18970 & .02748 & 4.84431 & 2.047 & 38 & .048 \\
\hline Pair 4 & $\begin{array}{l}\text { PHYSICAL dimension of } \\
\text { the uncertainty- } \\
\text { PHYSICAL dimension of } \\
\text { the uncertainty }\end{array}$ & 5.87179 & 6.88316 & 1.10219 & 3.64053 & 8.10306 & 5.327 & 38 & .000 \\
\hline
\end{tabular}

Testing null hypothesis $H_{02}$ :

An independent samples T-test was performed on the posttest uncertainty scores for all PBL learners. As indicated in the independent samples test statistics shown in Table 2, the p-value is more than 0.05 , the null hypothesis cannot be rejected. The following results are reported based on the Independent samples t-test statistics

$\mathrm{H}_{02}$ : There was no significant difference in the total uncertainty level for PBL learners with pretest $(\mathrm{M}=70.18, \mathrm{SD}=16.08)$ and without pretest (M=71.31, $\mathrm{SD}=10.82) ; \mathrm{t}(38)=-0.363, \mathrm{p}=0.074$

These results suggested that after undergoing the activities specified in the authentic PBL approach, there appeared no difference in the perception of total uncertainty level for both groups of PBL learners. This implied that pre-test did not affect the final uncertainty level of the PBL learners, hence this has indicated that there was learning taking place during problem solving process for all PBL learners in the authentic PBL 
Table 2: Independent samples T-Test

\begin{tabular}{|c|c|c|c|c|c|}
\hline \multicolumn{6}{|c|}{ Group Statistics } \\
\hline & group identifier & $\mathrm{N}$ & Mean & Std. Deviation & $\begin{array}{c}\text { Std. Error } \\
\text { Mean } \\
\end{array}$ \\
\hline \multirow[t]{2}{*}{$\begin{array}{l}\text { Total Uncertainty after } \\
\text { PBL }\end{array}$} & $\begin{array}{l}\text { experimental group with } \\
\text { pretest posttest }\end{array}$ & 39 & 70.1795 & 16.08018 & 2.57489 \\
\hline & $\begin{array}{l}\text { experimental group with } \\
\text { posttest only }\end{array}$ & 39 & 71.3077 & 10.82432 & 1.73328 \\
\hline
\end{tabular}

\begin{tabular}{|c|c|c|c|c|c|c|c|c|c|c|}
\hline \multicolumn{11}{|c|}{ Independent Samples Test } \\
\hline & & \multicolumn{2}{|c|}{$\begin{array}{l}\text { Levene's Test for Equality of } \\
\text { Variances }\end{array}$} & \multicolumn{7}{|c|}{ t-test for Equality of Means } \\
\hline & & \multirow[b]{2}{*}{$\mathrm{F}$} & \multirow[b]{2}{*}{ Sig. } & \multirow[b]{2}{*}{$t$} & \multirow[b]{2}{*}{ df } & \multirow[b]{2}{*}{ Sig. (2-tailed) } & \multirow{2}{*}{$\begin{array}{c}\text { Mean } \\
\text { Difference }\end{array}$} & \multirow{2}{*}{$\begin{array}{l}\text { Std. Error } \\
\text { Difference }\end{array}$} & \multicolumn{2}{|c|}{$\begin{array}{l}95 \% \text { Confidence Interval of the } \\
\text { Difference }\end{array}$} \\
\hline & & & & & & & & & $\begin{array}{l}\text { Lower } \\
\end{array}$ & Upper \\
\hline \multirow[t]{2}{*}{$\begin{array}{l}\text { Total Uncertainty after } \\
\text { PBL }\end{array}$} & $\begin{array}{l}\text { Equal variances } \\
\text { assumed }\end{array}$ & 3.291 & .074 & -.363 & 76 & .717 & -1.12821 & 3.10392 & -7.31020 & 5.05379 \\
\hline & $\begin{array}{l}\text { Equal variances not } \\
\text { assumed }\end{array}$ & & & -.363 & 66.571 & .717 & -1.12821 & 3.10392 & -7.32439 & 5.06798 \\
\hline
\end{tabular}

Testing null hypothesis $\mathrm{H}_{03}$ :

A paired-samples t-test was conducted to compare perception of satisfaction on learning experience of PBL learners before attempting and after completing learning task with the authentic PBL activities. As indicated in the paired sample t-test statistics shown in table 3 , the p-value was less than 0.05 , thus the Null hypothesis $\mathrm{H}_{03}$ was rejected and in favor of alternative hypothesis. The following results were reported based on the Paired sample t-test statistics

$\mathrm{H}_{3}$ : There was a significant difference in the perception of satisfaction in learning experience for PBL learners before Authentic PBL $(\mathrm{M}=3.70, \mathrm{SD}=0.48)$ and after Authentic PBL $(\mathrm{M}=3.93, \mathrm{SD}=0.38) ; \mathrm{t}(38)=-2.55, \mathrm{p}=0.015$.

These results suggested that the authentic PBL approach really did have influence on perception on satisfaction in learning experience. Specifically, our results suggested that when PBL learners underwent the activities specified in the authentic PBL approach, their perception on satisfaction in learning experience has increased. This has indicated that it was consistent with the results in the first hypothesis, i.e., there was learning taking place during problem solving process in the authentic PBL.

Table 3: Paired Samples T-Test

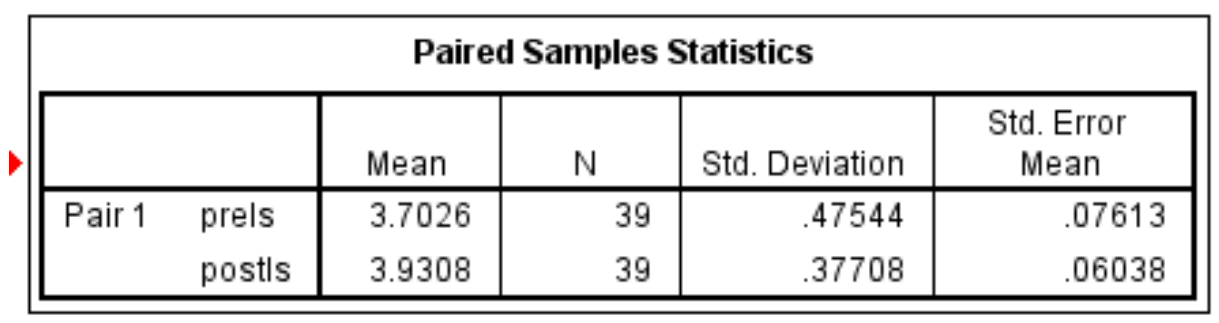

\begin{tabular}{|c|c|c|c|c|c|c|c|c|}
\hline \multicolumn{9}{|c|}{ Paired Samples Test } \\
\hline & \multicolumn{5}{|c|}{ Paired Differences } & \multirow[b]{3}{*}{$t$} & \multirow[b]{3}{*}{ df } & \multirow[b]{3}{*}{ Sig. (2-tailed) } \\
\hline & \multirow[b]{2}{*}{ Mean } & \multirow[b]{2}{*}{ Std. Deviation } & \multirow{2}{*}{$\begin{array}{l}\text { Std. Error } \\
\text { Mean }\end{array}$} & \multicolumn{2}{|c|}{$\begin{array}{l}\text { 95\% Confidence Interval of the } \\
\text { Difference }\end{array}$} & & & \\
\hline & & & & Lower & Upper & & & \\
\hline Pair 1 prels - postls & -.22821 & .55911 & .08953 &. .40945 & -.04696 & -2.549 & 38 & .015 \\
\hline
\end{tabular}

Testing null hypothesis $H_{04}$ :

An independent samples T-test was performed on the posttest perception on satisfaction in learning experience for all PBL learners. As indicated in the independent samples test statistics shown in Table 4 , the p-value was more than 0.05 , the null hypothesis cannot be rejected. The following results were reported based on the Independent samples t-test statistics

$\mathrm{H}_{04}$ : There was no statistical significant difference in the perception of satisfaction in learning experience for PBL learners with pretest $(\mathrm{M}=3.93, \mathrm{SD}=0.38)$ and without pretest $(\mathrm{M}=3.91, \mathrm{SD}=0.43) ; \mathrm{t}(38)=-0.225, \mathrm{p}=0.94$.

These results suggested that after underwent the activities specified in the authentic PBL approach, there appeared no difference in the perception of satisfaction in learning experience for both groups of PBL learners. This implied that pre-test did not affect the perception of satisfaction in learning experience of the PBL learners, hence this has indicated that there was learning taking place during problem solving process in the authentic PBL 
Table 4: Independent Samples T-test

\begin{tabular}{||ll|r|r|r|r|}
\hline \multicolumn{7}{|c|}{ Group Statistics } \\
\hline postls & $\begin{array}{l}\text { experimentifier } \\
\text { pretest posttest } \\
\text { experimental group with } \\
\text { posttest only }\end{array}$ & $\mathrm{N}$ & Mean & Std. Deviation & $\begin{array}{c}\text { Std. Error } \\
\text { Mean }\end{array}$ \\
\hline
\end{tabular}

\begin{tabular}{|c|c|c|c|c|c|c|c|c|c|c|}
\hline \multicolumn{11}{|c|}{ Independent Samples Test } \\
\hline & & \multicolumn{2}{|c|}{$\begin{array}{l}\text { Levene's Test for Equality of } \\
\text { Variances }\end{array}$} & \multicolumn{7}{|c|}{ t-test for Equality of Means } \\
\hline & & \multirow[b]{2}{*}{$\mathrm{F}$} & \multirow[b]{2}{*}{ Sig. } & \multirow[b]{2}{*}{$t$} & \multirow[b]{2}{*}{ df } & \multirow[b]{2}{*}{ Sig. (2-tailed) } & \multirow{2}{*}{$\begin{array}{c}\text { Mean } \\
\text { Difference }\end{array}$} & \multirow{2}{*}{$\begin{array}{l}\text { Std. Error } \\
\text { Difference }\end{array}$} & \multicolumn{2}{|c|}{$\begin{array}{l}95 \% \text { Confidence Interval of the } \\
\text { Difference }\end{array}$} \\
\hline & & & & & & & & & Lower & Upper \\
\hline postls & $\begin{array}{l}\text { Equal variances } \\
\text { assumed }\end{array}$ & .006 & .940 & .225 & 76 & .822 & .02051 & .09102 & -16078 & .20180 \\
\hline & $\begin{array}{l}\text { Equal variances not } \\
\text { assumed }\end{array}$ & & & .225 & 74.922 & .822 & .02051 & .09102 & -16082 & .20185 \\
\hline
\end{tabular}

Testing null hypothesis $H_{05}$ :

A Pearson product-moment correlation was computed to assess correlation between decrease in PBL learners' uncertainty level and increase in rating in satisfaction of learning experience for the group with pretest and post-test. The statistical analysis revealed that decrease in PBL learners' uncertainty level and increase in satisfaction in learning experience were positively related and that the correlation was statistically significant $(r=0.402, n=39, p<0.05$, two-tailed). Thus, null hypothesis $\mathrm{H}_{05}$ was rejected in favor of its alternative hypothesis. It follows that there is a statistically significant, positively correlation between decrease in PBL learners' uncertainty level and increase in rating of satisfaction in learning experience. This statistical analysis revealed that PBL learners' uncertainty level was resolved during the problem solving process of the authentic PBL classroom, which corresponds to increase in satisfaction in their learning experience.

Table 5: Pearson's Moment Correlation Test

\begin{tabular}{|c|c|c|c|}
\hline \multicolumn{4}{|c|}{ Correlations } \\
\hline & & $\begin{array}{l}\text { decreaseinU } \\
\text { NCERTAINTY }\end{array}$ & $\begin{array}{l}\text { increaseinlea } \\
\text { rningsatisfacti } \\
\text { on }\end{array}$ \\
\hline $\begin{array}{l}\text { decreaseinUNCERTAINT } \\
Y\end{array}$ & $\begin{array}{l}\text { Pearson Correlation } \\
\text { Sig. (2-tailed) } \\
\mathrm{N}\end{array}$ & $\begin{array}{r}1 \\
39\end{array}$ & $\begin{array}{r}.402 \\
.011 \\
39\end{array}$ \\
\hline $\begin{array}{l}\text { increaseinlearningsatisfa } \\
\text { ction }\end{array}$ & $\begin{array}{l}\text { Pearson Correlation } \\
\text { Sig. (2-tailed) } \\
\mathrm{N}\end{array}$ & $\begin{array}{r}.402 \\
.011 \\
39\end{array}$ & $\begin{array}{r}1 \\
39\end{array}$ \\
\hline
\end{tabular}

Conclusion:

The initial higher level of uncertainty as compare to the lower level of uncertainty perceived by the PBL learners after successfully completed the learning task provide the evidence of incorporation of uncertainty in the learning tasks in authentic PBL classroom. The uncertainty may have reduced in each stage of problem solving process after seeking the information to fill the gap. The increase in the perceived satisfaction in their learning experience also indicate the learning is really taking place during the problem solving process. The results of statistical analysis have confirmed that the authentic PBL approach will assist PBL learners to overcome the anxiety due to uncertainty incorporated in the authentic learning task with the prescribed PBL process (TIPS) described in the authentic PBL model. The learners also marked an increase in their rating to satisfaction in learning experience after completing the learning tasks. A positive correlation between the decrease in level of uncertainty and increase in rating of satisfaction in learning experience was recorded. The authentic PBL classroom empowers the PBL learners to identify in advance and plan with explicit learning objectives based on the knowledge, skills and attitudes required to perform the learning tasks which mimic the "real world" problem.

\section{REFERENCES}

[1] Blumenfeld, S., 2000. The importance of rote learning: Behind the Scenes. Practical Home schooling, p: 37.

[2] World Health Organisation, 1987. Innovative tracks as established institutions for the education of health personnel. Geneva: WHO.

[3] Burch, K., 2000. A primer on problem-based learning for international relations courses. International Studies Perspectives, 1: 31-44.

[4] Spender, D. and F. Stewart, 2002. Embracing e-learning in Australian schools. Brisbane: Commonwealth Bank.

[5] Boyer Commission Report, 1998. Reinventing undergraduate education: A blueprint for America's research universities. New York: The Carnegie Foundation for the Advancement of Teaching.

[6] Savery, J.R. and T.M. Duffy, 1995. Problem-based learning: An instructional model and its constructivist framework. In Wilson, B. (eds.), Constructivist learning environments: Case studies in instructional design (pp. 135-148). Englewood Cliffs: Educational Technology Publications.

[7] Lee, V.S., 1998. The uses of uncertainty in the college classroom. Essays on Teaching Excellence, 12(1). Fort Collins, CO: POD Network in Higher Education.

[8] Wee, K.N.L., 2004. Jump Start Authentic Problem Based Learning. Singapore: Prentice Hall Pearson Education South Asia Pte. Ltd.

[9] Wee, K.N., Y.C. Kek, G. Silva and T.H. Seah, 2000. Tried \& tested: issues \& implications for educators in problem-based learning: relearning from the learners' perspective. Paper presented at the $2^{\text {nd }}$ Asia Pacific conference in Problem-based Learning organised by Temasek Polytechnic, Singapore.

[10] Brandes, D. and P. Ginnis, 1986 A Guide to Student Centred Learning. (Oxford, Blackwell)

[11] Hurst, J. and S. Quinsee, 2004. A quality framework for producing clinically competent nurses through distance education, European Journal of Open, Distance and E-learning. Available st www.eurodl.org/materials/contrib/2004/Hurst_Quinsee.htm.

[12] Khairiyah Mohd Yusof, et al. 2004. Problem based learning in engineering education: A viable alternatives for shaping graduates for the $21^{\text {st }}$ century. Paper presented at the Conference on Engineering Education, Kuala Lumpur.

[13] Woods, D.R., 2007a. Helping Students Gain the Most from their PBL Experience. Management of Change, edited by Graaff, E. De and Kolmos, A., pp: 181195. Sense Publishers.

[14] O’Grady, G. et al. (eds), 2012. One-Day, One-Problem: An Approach to Problem-based Learning, DOI 10.1007/978-981-4021=75-3_1. Springer Science+Business Media Singapore

[15] Wilson, T.D., 1999. Model in information behavior research. Journal of Documentation, 55(3): 249-270. 